\title{
GROWTH EFFECTS OF MIGRANTS' REMITTANCES IN SELECTED SUB-SAHARAN AfRICAN COUNTRIES
}

\author{
Taiwo Ajilore* \\ University of Fort Hare \\ ajilore@ufh.ac.za \\ Sylvanus Ikhide* \\ University of Fort Hare \\ sikhide@ufh.ac.za
}

Received: July 2011

Accepted: January 2013

\begin{abstract}
The study examined the assumption that 'size matters' in the empirical controversy of the relationship between migrants' remittances and economic growth. This is done through an empirical analysis of the remittances-growth relationships in selected countries in Sub-Saharan Africa, where remittance inflows are overwhelming proportions of real GDP. The study used data at the country level, for five countries: Cape Verde, Lesotho, Nigeria, Senegal and Togo. The long-run ARDL estimates indicate positive and significant effects of migrants' remittances on growth performance in Cape Verde and Nigeria, but negative, and slightly significant effects for Lesotho, with no evidence of long-run level relationships between remittances and economic growth in Senegal and Togo. Thus, the assumption that size may matter in the remittance-growth nexus finds no support, as findings provide no significant departure from the existing inconclusiveness of empirical literature on the relationship. For policy, the study advocates country-level policies that improve the efficiency of remittance inflows and promote the use of remittances for developmental purposes.
\end{abstract}

Keywords

Remittances, magnitudes, economic growth, ARDL model, SSA

*Mr Taiwo Ajilore is a post-doctoral research fellow at the University of Fort Hare, South Africa.

\#Prof Sylvanus Ikhide is Nedbank Chair in Economics and professor at University of Fort Hare, South Africa. 


\section{INTRODUCTION}

Economic theory considers economic growth a basic prerequisite for escaping the poverty trap; nevertheless, sustainable economic growth remains an intractable developmental challenge to many poor countries of the Sub-Saharan Africa region. This is exacerbated by the widening financing gap to address core developmental problems, accentuated by traditional sources of finance that have proved to be inadequate in quantity and composition. In particular, as a consequence of the recent global financial crisis, Official Development Assistance (ODA) and Foreign Direct Investment (FDI), the major sources of external finance, witnessed substantial slowdowns as a share of GDP over the last decades.

For poor countries that are constrained by scarce and meagre foreign exchange sources for development financing, non-traditional sources of finance such as remittances have grown in importance in the last decade, particularly in many African countries. Remittances referred to that portion of migrants' earnings sent from the migration destination to the place of origin. While remittance can be sent in cash or kind, the term is mostly restricted to monetary and other cash transfers transmitted by migrant workers to their families and communities back home. The unique characteristics of remittances as a source of foreign exchange earnings make it an attractive source of growth and development financing. Chami et al. (2009) identified three main features of remittances that have attracted the attention of policymakers and researchers in recent years: the size of these flows relative to the size of the recipient economies, the likelihood that these flows will continue unabated into the future through continued globalisation trends, and the fact that these flows are quite distinct from those of other bilateral flows such as official aid or private capital, which are subject to a high degree of uncertainty, denying policymakers the much-needed degrees of freedom in making investment plans (Shimeles, 2010).

These issues become particularly relevant for countries in Sub-Saharan Africa, given the phenomenal growth profile of remittances receipts by them in recent years, which makes them an interesting case study of the potential growth promoting effects of migrants' remittances. Although most of the reported global remittance flows go to regions other than Sub-Saharan Africa (SSA), the region has been part of the overall rising global trend in remittance inflows to labour-exporting countries. Especially for some countries in the sub-region, the growth profile of remittance receipts in recent times has been phenomenal.

Remittances accounted for well over 10\% of GDP in Cape Verde consistently for the period 2000 to 2010. In comparison to other sources of resource inflows, remittances consistently outstrip foreign direct investment (FDI) and compete well with inflows of overseas development assistance (ODA) in terms of prominence. Lesotho ranked third among top remittance-receiving countries globally in 2009, and in terms of economic dependence on remittance inflows, it ranks highest in Sub-Saharan Africa, with remittances-GDP ratios ranging between $34 \%$ in 2000 and $26 \%$ in 2009 . While Nigeria has a moderate (mostly below $5 \%$ ) proportion of remittances in its GDP composition, it stands out prominently in the profile of aggregate remittance inflows into Sub-Saharan Africa as a whole. In 2010, for instance, Nigeria was tenth in global ranking and SSA's highest recipient of remittances of over US\$10 billion, accounting for about $50 \%$ of total inflows of remittances to Sub-Saharan Africa. Ranking equally prominently on the list of top-ten remittance recipients in Sub-Saharan Africa are Senegal and Togo, with recent evidence suggesting that remittances constitute substantial proportions of their national earnings. In recent years, the proportion of remittances in their GDP has remained in excess of $10 \%$ and 
outpaces other sources, including foreign direct investment and overseas development assistance.

A growing amount of empirical analysis of growth effects of remittance on developing countries has emerged. However, available empirical evidence on the relationship is quite ambiguous and still presents an open question. While there are views that remittances reduce the incentive to work in recipient countries, thus having a negative effect on economic growth (see Chami et al., 2003), there are converse arguments that remittance flows have a positive impact on recipientcountry growth, as they finance both consumption and investment and ease the balance of payments situation in foreign-exchange-constrained economies (see Solimano, 2003). The International Monetary Fund (2005) finds no relationship at the country level between remittances and growth in a worldwide sample of about 100 countries over the period 1970 to 2003.

Given the preponderance of remittance flows to the aforementioned countries, they may be expected to have important implications for economic growth in these countries. This paper aims to contribute to the migration literature in SSA by looking specifically at countries with a preponderance of remittance flows within the sub-region; this achieves a richer analysis of the role of remittances in the growth performance in the region than those provided by studies with cross-country analyses across all African countries and country studies where remittance inflows are an insignificant proportion of GDP or other sources of financial inflows.

This study therefore aimed to re-examine the growth effects of migrants' remittances, using country-level data for the periods 1985 to 2010 in five selected Sub-Saharan African countries Cape Verde, Lesotho, Nigeria, Senegal and Togo - to determine the short- and long-run impact of remittances on economic growth. The study uses the Auto-Regressive Distributed Lag (ARDL) bounds testing approach for testing the existence of a co-integration relationship. The approach has certain econometric advantages in comparison to other single co-integration procedures. Despite these advantages, existing studies on the remittances-growth nexus have not made sufficient use of the approach.

The rest of the paper proceeds as follows: following this introduction, section 2 provides an analysis of the trends of remittance inflows to the selected Sub-Saharan African countries. Section 3 deals with the theoretical framework and empirical evidence on the remittancesgrowth relationships, while section 4 elaborates on the empirical and modelling procedures used in the study. Section 5 presents and discusses the empirical findings, while section 6 concludes the study.

\section{TRENDS OF REMITTANCE FLOWS IN SUB-SAHARAN AFRICA}

Sub-Saharan Africa as a group lags behind other developing regions in terms of magnitude of remittances receipts. As indicated in TABLE 1 , remittances to the region in 2009 amount to US\$20.7 billion, accounting for a meagre $6.7 \%$ of remittance flows to all developing countries, compared to countries in Latin America and the Caribbean, as well as East Asia and the Pacific with above $25 \%$ share. The indicated record generally obscures the true size of remittances for all recipient countries, because the IMF reports data on official worker remittance flows, that is, remittance monies which are transmitted through official banking channels, leaving those transmitted through private unofficial channels unaccounted for. In particular for Sub-Saharan Africa, the true amount of remittances is least accurately estimated relative to other 
developing regions of the world. Freund and Spatafora (2005) estimated that 45 to $65 \%$ of remittance flows to Sub-Saharan Africa are informally routed, compared to only about 5 to $20 \%$ in Asian and Latin American countries respectively. This is mainly accounted for by the rudimentary nature of the financial and other fund-transmission mechanisms, which leads to relatively high transaction costs in most African financial markets and favours informal transmission channels, especially for small transfers.

Relative to Gross National Product, remittances have maintained a consistently increasing share in Sub-Saharan Africa, increasing from a 1.5\% share of GDP in 2000 to $2.5 \%$ in 2009, which compares favourably with Latin America (1.5\%), South Asia (4.8\%), East Asia (1.9\%). Relative to other sources of financial flows, remittances still remain considerably lower than other sources like foreign direct investment (FDI) and overseas development assistance (ODA).

TABLE1: Trend of Remittances, and other Resource Flows to Sub-Saharan Africa: 2000 - 2009

\begin{tabular}{|c|c|c|c|c|c|c|c|c|c|c|c|}
\hline & & 2000 & 2001 & 2002 & 2003 & 2004 & 2005 & 2006 & 2007 & 2008 & 2009 \\
\hline \multirow{4}{*}{ 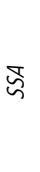 } & Remittances (US\$b) & 4.6 & 4.7 & 5.1 & 5.9 & 8.0 & 9.4 & 12.6 & 18.6 & 21.6 & 20.7 \\
\hline & Remittances (\% GDP) & 1.5 & 1.6 & 1.6 & 1.5 & 1.6 & 1.6 & 1.9 & 2.4 & 2.3 & 2.5 \\
\hline & FDI ( $\%$ of GDP) & 2.0 & 4.5 & 3.8 & 3.13 & 2.1 & 2.9 & 2.7 & 3.4 & 3.6 & 3.4 \\
\hline & ODA $(\%$ of GDP $)$ & 3.5 & 3.9 & 4.8 & 5.1 & 4.4 & 4.7 & 5.0 & 3.6 & 3.4 & 3.8 \\
\hline \multirow{4}{*}{ 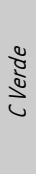 } & Remittances(US\$ m) & 86.9 & 80.9 & 85.1 & 108.5 & 113.3 & 136.6 & 136.7 & 138.9 & 155.1 & 146.1 \\
\hline & Remittances ( $\%$ GDP) & 16.3 & 14.7 & 13.8 & 13.6 & 12.3 & 13.7 & 12.3 & 10.4 & 10.1 & 9.4 \\
\hline & FDI ( $\%$ of GDP) & 6.3 & 1.6 & 2.4 & 4.9 & 7.3 & 8.1 & 11.9 & 14.4 & 13.7 & 7.7 \\
\hline & ODA ( $\%$ of GDP) & 17.6 & 14.1 & 14.8 & 18.4 & 15.4 & 16.1 & 11.5 & 11.4 & 12.6 & 12.1 \\
\hline \multirow{4}{*}{ 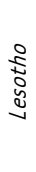 } & Remittances (US\$ m) & 252.2 & 209.4 & 194.2 & 287.9 & 354.9 & 326.5 & 361.4 & 451.1 & 438.5 & 414.1 \\
\hline & Remittances (\% GDP) & 33.8 & 30.5 & 30.4 & 30.3 & 29.4 & 24.8 & 25.5 & 28.6 & 27.5 & 26.2 \\
\hline & FDI (\% of GDP) & 15.8 & 17.1 & 13.1 & 12.2 & 10.2 & 7.1 & 7.9 & 8.2 & 4.5 & 3.9 \\
\hline & ODA $(\%$ of GDP $)$ & 4.6 & 7.7 & 11.4 & 7.9 & 7.6 & 4.90 & 4.6 & 7.7 & 8.8 & 8.7 \\
\hline \multirow{4}{*}{$\begin{array}{l}\frac{a}{2} \\
\frac{0}{2} \\
\frac{10}{2}\end{array}$} & Remittances (US\$ m) & 1392 & 1167 & 1209 & 1063 & 2273 & 3329 & 5435 & 9221 & 9980 & 9584 \\
\hline & Remittances ( $\%$ GDP) & 3.1 & 2.4 & 2.1 & 1.6 & 2.58 & 2.9 & 3.7 & 5.6 & 4.8 & 5.5 \\
\hline & FDI ( $\%$ of GDP) & 2.5 & 2.5 & 3.2 & 2.9 & 2.13 & 4.43 & 6.0 & 3.6 & 2.7 & 3.3 \\
\hline & ODA (\% of GDP) & 0.2 & 0.1 & 0.1 & 0.2 & 0.3 & 0.4 & 0.4 & 0.3 & 0.3 & 0.3 \\
\hline \multirow{4}{*}{ 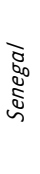 } & Remittances (US\$ m) & 233.5 & 304.7 & 344.5 & 510.9 & 632.9 & 788.8 & 925.2 & 1192 & 1476 & 1365 \\
\hline & Remittances ( $\%$ GDP) & 4.9 & 6.3 & 6.5 & 7.4 & 7.9 & 9.1 & 9.9 & 10.5 & 11.2 & 10.6 \\
\hline & FDI ( $\%$ of GDP) & 1.3 & 0.7 & 1.46 & 0.8 & 0.9 & 0.5 & 2.3 & 2.6 & 5.3 & 1.6 \\
\hline & ODA (\%of GDP) & 9.0 & 8.7 & 8.4 & 6.6 & 13.1 & 7.8 & 8.7 & 7.7 & 8.0 & 8.4 \\
\hline \multirow{4}{*}{$\begin{array}{l}\circ \\
5 \\
\circ\end{array}$} & Remittances(US\$ m) & 34.2 & 68.5 & 103.2 & 148.6 & 179.0 & 192.5 & 232.1 & 284.5 & 337.1 & 306.8 \\
\hline & Remittances ( $\%$ GDP) & 2.6 & 5.2 & 7.0 & 8.5 & 8.7 & 9.1 & 10.5 & 11.4 & 11.6 & 10.7 \\
\hline & FDI ( $\%$ of GDP) & 3.2 & 4.8 & 3.6 & 1.9 & 2.9 & 3.7 & 3.5 & 1.9 & 2.3 & 1.8 \\
\hline & ODA (\% of GDP) & 5.2 & 3.4 & 3.4 & 2.8 & 3.1 & 3.9 & 3.6 & 4.8 & 4.7 & 4.1 \\
\hline
\end{tabular}

Source: Authors' compilations from World Bank Development Indicators Database (Online), International Financial statistics (IMF) Database, and IMF World Economic Outlook Database.

In sharp contrast to the unexceptional profile of remittance flow to the region as a group, the selected countries of Cape Verde, Lesotho, Nigeria, Senegal and Togo present an interesting case study of the link between remittances and economic development, with the magnitudes and 
proportions of remittance flows to these economies. Cape Verde has one of the world's highest migrancy rates, with emigrants ranging between $35.8 \%$ of the population in 2005 and $37.5 \%$ in 2010 , ranking third on the list of the top-ten remittance recipients in Sub-Saharan Africa in 2006 and 2009. As TABLE 1 indicates, remittances accounted for well over 10\% of GDP in Cape Verde consistently for the period 2000 to 2010. In comparison to other sources of resource inflows, remittances consistently outstrip foreign direct investment (FDI) and compete well with inflows of overseas development assistance (ODA) in terms of prominence. Lesotho ranked third among top remittance-receiving countries globally in 2009; and in terms of economic dependence on remittance inflows, it ranked highest in Sub-Saharan Africa, with the remittances-GDP ratio ranging between $34 \%$ in 2000 and $26 \%$ in 2009 . The pre-eminence of remittance flows to the Lesotho economy is further demonstrated by the fact that they were consistently more than double FDI and ODA flows as a proportion of GDP for the entire period 2000 to 2009.

While Nigeria has a moderate (mostly below 5\%) proportion of remittances in its GDP composition, it stands out prominently in the profile of aggregate remittance inflows into SubSaharan Africa as a whole. In 2010, for instance, Nigeria was the tenth in global ranking and SSA's highest recipient of remittances of over US\$10 billion, accounting for about $50 \%$ of total inflows of remittances to Sub-Saharan Africa. As FIGURE 1 indicates, remittances remain a prominent source of external finance in the Nigeria's economy, as they widely outpace overseas development assistance, and on average are par with foreign direct investment during the period 2000 to 2009. Ranking equally prominently on the list of top-ten remittance recipients in Sub-Saharan Africa is Senegal and Togo, with recent evidence suggesting that remittances constitute a substantial proportion of their national earnings. In recent years, the proportions of remittances in their GDP have remained in excess of $10 \%$ and outpace other sources, including foreign direct investment and overseas development assistance.

\section{LITERATURE REVIEW}

\subsection{Theoretical issues}

The traditional focus of research on remittances has been on their use and their effects on recipient households, including their effects on poverty at the micro-economic household level. But the large and increasing size of remittances relative to other external flows and to the GDP in many poor, labour-exporting countries suggests that the macro-economic effects of remittances may be of critical importance to these countries. At the level of the household, there is a consensus of opinion that remittances reduce poverty, help even household consumption, ease working capital constraints on farms and small-scale entrepreneurs, and lead to increased household expenditure in areas considered to be important for development particularly education, entrepreneurship, and health (see, inter alia, World Bank, 2006; 2010 for a review of these issues).

However, the macro-economic question of the growth effects of migrants' remittances in recipient countries remains largely unanswered by existing theoretical contributions on the subject. The inconclusive arguments on the subject range from concerns over whether remittances could have significant impact on economic growth, to theoretical and plausible channels through which remittances could raise economic growth, and several factors that could result in remittances hampering GDP growth. 
A number of studies (Stark \& Levhari, 1982; Ahlburg, 1991) point out that the primary use of remittances has been for consumption, with the remainder being used for house construction, debt repayment and the financing of future migration. According to this view, remittances have raised levels of consumption without creating a firm basis within the domestic economy. The lack of investment in productive activities casts doubt on the role of remittances in generating economic growth.

Several channels through which remittances could raise economic growth have been identified in the literature: remittances may smooth consumption and contribute to the stability of recipient economies by compensating for foreign exchange losses due to adverse macro-economic shocks. Remittances may rise when the recipient economy suffers a downturn in activity or macro-economic shocks, because migrants may send more funds during hard times to help their families and friends. Yang (2005) shows that remittance receipts by Filipino households increased following the 1997 financial crisis. Mishra (2005) finds that a $1 \%$ decrease in real GDP was associated with a $3 \%$ increase in remittances after a two-year lag in 13 Caribbean countries during 1980 to 2002. Yang (2005) found that the increase in remittances makes up for $13 \%$ of income losses in the current year and $28 \%$ within four years of a hurricane, more than does increases in ODA and FDI.

Various studies, including the IMF (2005), World Bank (2006) and Chami et al. (2008), have documented that remittances smoothen or reduce volatility in output, on the one hand, while Ramey and Ramey (1995), Kroft and Lloyd-Ellis (2002), Hnatkovska and Loayza (2003) have established that volatility and growth are inversely related.

Remittances can improve a country's creditworthiness and thereby enhance its access to international capital markets. The World Bank (2006) indicates that model-based calculations using debt-to-export ratios that include remittances in the denominator would improve creditworthiness assessments and credit ratings for Lebanon and Haiti by two scale points; these would result in implied sovereign spread reductions ranging from 130 to 334 basis points. Remittances also help stabilise the current account by reducing the volatility of overall capital flows (Chami et al., 2009). Remittances can reduce the probability of current account reversals, especially when they exceed $3 \%$ of GDP (Bugamelli \& Paterno, 2009).

Ratha (2005) and Ketkar and Ratha (2009a), among others, emphasised the potential use of future remittances as collateral to raise financing from international capital markets for financing development projects at lower costs and longer maturities by African countries. Future remittance-backed bonds can potentially be issued with amounts ranging from a tenth to a fifth of their annual remittance flows, depending on the level of over-collateralisation required to implement these transactions. The World Bank (2011) estimates the potential for securitisation of remittances and other future receivables at $\$ 35$ billion annually for Sub-Saharan Africa.

Another channel through which remittances may have a positive impact on growth is via the significant productivity spill-overs that may result from the recipients, especially given the assumption that they participate in the labour market. A significant fraction of remittances is spent on education, which facilitates human capital formation, and ultimately increases total factor productivity. In addition, the majority of remitted funds are devoted to consumption and residential investment, which improves nutrition and shelter and the quality and output of the labour unit.

Finally, remittances may have a positive impact on growth through their effect on the recipient economy's financial system. Fajnzylber and Lopez (2008) and Gupta et al. (2009) documented a 
positive, significant and robust link between remittance and financial development, going with the consensus of opinion on the fact that financial development fosters pro-poor growth (Levine, 2005; Beck, 2009). This is based on the notion that money transferred through financial institutions paves the way for recipients to demand and gain access to other financial products and services that they otherwise might not have, and, at the same time, when remittance payments are made through financial institutions, the receiving banks can reach out to recipients without bank accounts to offer them financial products and services, thus reaching out to "unbanked" recipients. Orozco and Fedewa (2005) provide accounts of financial institutions' attempts to "bank" remittance recipients by lowering remittance fees and by offering specially designed products, and suggest that financial institutions perceive the likely impact of remittances on financial development to be positive. Moreover, even if higher bank lending to remittance recipients does not materialise, overall credit in the economy might increase if banks' loanable funds surge as a result of deposits linked to remittance flows.

However, concerns that remittances can decrease economic growth through channels that operate differently from the aforementioned have been expressed through three main channels: moral hazard, the Dutch-disease effects of remittance inflows, and their disproportionate financing of consumption.

The moral hazard channel was popularised by Chami et al. (2003). The moral hazard problem in remittance transfers arises as a result of asymmetric information between the remitter and recipient of the transfer, who are separated by long distances. In addition, unlike other formal financial flows, remittances are compensatory transfers motivated by altruism, and as such monitoring and enforcement clauses are not included in the transfer arrangement. This may become extremely difficult to enforce because of the distance between the remitter and the recipient. The moral hazard problem manifests in the reduction of the labour market effort of the recipients and engaging in risky investment of the remitted funds. Chami, Gapen and Cosimano (2006), using a dynamic general equilibrium model with remittances, show that these flows reduce labour supply. Kozelt and Alderman (1990) studied labour force participation and labour supply in Pakistan and found a significant negative impact of remittances on the labour force participation of males. Similarly, Itzigsohn (1995) also found, in a sample of Caribbean Basin cities, that remittances significantly reduce the labour force participation of household heads as well as other members of remittance-receiving families.

The Dutch-disease effect may arise from excessive remittance inflows that induce appreciation of the real exchange rate to the disadvantage of the profitability and production of tradable goods. Acosta, Lartey, and Mandelman (2007) document empirical evidence on the Dutchdisease effects of remittances in $\varepsilon \mid$ Salvador. Amuedo-dorants and Pozo (2004) confirmed that workers' remittances inflict economic costs on the export sectors of a panel of 13 Latin American and Caribbean countries by reducing their international competitiveness through real exchange-rate appreciation. Finally, Kapur and McHale (2005) have argued that remittances may have a minimal impact on saving and investment since they are used mainly for daily consumption and may promote idleness among those who benefit.

\subsection{Empirical evidence}

The lack of research on the growth effects of remittances in Sub-Saharan Africa serves as the raison d'être for the current study. Empirical studies on the impact of remittances on economic growth are few and begin to emerge mainly after the seminal Chami et al. (2003) study on the subject. Chami et al. (2008) has attributed this development to recent improvements in the 
quality of data on remittances, which has made cross-country analysis of the subject feasible. Accordingly, studies using large sets of cross-country data have emerged.

Chami et al. (2003) conducted panel regressions, using a sample of 83 countries during the 1970-1998 period to examine the effects on growth in real GDP per capita of both the workers' remittances-to-GDP ratio and the change in that ratio, conditioned on the investment rate, the rate of inflation, regional dummies, and the ratio of net private capital flows to GDP. The study controlled for possible endogeneity of remittances to the macro-economic control variables, and concluded that workers' remittances-to-GDP ratio either was not significant or was negatively related to growth, under various specifications. They attributed this outcome to the moral hazard problem (i.e., reduced labour market participation), as well as other factors outlined above, and question whether remittances can be a source of development capital.

Giuliano and Ruiz-Arranz (2005) examined the possibility that remittances could be more, or less, effective in stimulating economic growth when associated with a financial depth variable. The study consists of a sample of 73 countries during the 1975 to 2002 periods, and uses OLS as well as fixed-effects panel estimates through the system generalised method of moments (SGMM) procedure with internal instruments to account for possible endogeneity. The authors found all the alternative specifications and the interaction term between remittances and financial depth to be negative. They concluded that remittances appeared to have positive effects on growth only in countries with small financial sectors where presumably credit constraints would be more pervasive.

In a cross-section study of 101 countries over the 1970 to 2003 period, the IMF (2005) uses two instruments for remittances: distance between the migrants' home and main destination country, and a dummy measuring whether the home and main destination country shared a common language. The study documented no statistically significant effect of remittances on economic growth.

Faini (2006) estimated cross-sectional growth regressions on a set of 68 countries from 1980 to 2004 using ordinary least-squares (OLS) regression. Faini's study, like that of the IMF (2005), measured remittances as the sum of workers' remittances, employee compensation, and migrant transfers. The estimated coefficient on the total remittances-to-GDP ratio was positive and significant. The study also conducted instrumental variables estimation, using distance from the migrants' main destination countries as the instrument for remittances. In this estimation, the coefficient on total remittances remained positive but insignificant.

Catrinescu et al.'s (2008) study consists of cross-sectional as well as various static and dynamic panel regressions on a dataset of 114 countries during the 1991 to 2003 period. The study emphasised the roles of institutions on the growth-promoting effects of remittances; consequently it extends previous work by incorporating institutional variables into the analysis. Though they found some evidence of a positive relationship between growth and the (log of the) remittance ratio, they concluded that this relationship was not very robust and was relatively mild.

Pradhan et al. (2008) examine the effect of workers' remittances on economic growth in a sample of 39 developing countries using panel data from 1980 to 2004 to estimate a standard growth model using both fixed-effects and random-effects approaches. The empirical results show that remittances have a positive impact on growth. 
Barajas et al. (2009) use a dataset that includes 84 countries from 1970 to 2004 - the longest period and broadest set of countries for which remittance data is available. Using an instrumental variables approach, the study finds little impact of remittances on growth.

Cruz Zuniga (2011) investigates the impact of remittances at the macro-economic level in a sample of 122 developing countries over the period 1980 to 2005, controlling for endogeneity problems with the use of panel vector auto regression (panel VAR). The findings suggest that remittances have a positive, albeit small, impact on economic growth even without considering the role of institutions. When institutions are included, the pattern of response remains unaltered. A distinction between low versus high remittance participation in economic activity reveals that although the impact of remittances on growth is similar, appreciation of the exchange rate occurs in economies with high remittance participation. Finally, a distinction by geographical region reveals that Eastern European economies receive the greatest benefit from these flows, followed by the Americas and Asia; however, African economic growth does not appear to have a statistically significant impact.

Rao and Hassan (2011) analyse the direct growth effects of remittances and the channels through which remittances affect growth by treating the latter as part of the conditioning variables. The study used a sample consisting of 40 countries with remittances to GDP ratio of $1 \%$ or more and panel data estimation and also a modified specification and the system GMM method, which minimises the weak instruments problem. The study finds that the direct growth effects of remittances are insignificant. However, remittances may have small indirect growth effects. The study identified investment and development of the financial sector as the two channels through which remittances may have indirect growth effects.

The reviews presented above not only leave open the question regarding the effects of migrants' remittances on growth performance, but results from these cross-country analysis also become difficult to generalise to the peculiar experiences of countries of Sub-Saharan Africa without violating the implicit assumption of 'homogeneity' in the observed relationship across countries. This is because Sub-Saharan Africa possesses considerable differences in terms of structural features and institutions that shape the remittance-growth relationship. Notwithstanding that Sub-Saharan Africa has been part of the overall rising global trend in remittance inflows in the past decade, with remarkable growth profiles in some of the countries, empirical research with exclusive focus on its growth inducement potential in the sub-region is still weak and recent, with equally inconclusive results.

Fayissa and Nsiah (2008) investigated the impact of remittances on economic growth for 37 African countries. The study showed that migrants' remittances as well as institutional variable have positive impacts on economic growth.

Baldé (2009) investigated the relationship between remittances and growth in SSA. From a sample of 29 SSA countries for the 1980 to 2004, the study found that remittances do not have any direct impact on the economic growth of Sub-Saharan African countries. The study however postulates the possibility that remittances may have an indirect positive impact on growth through several channels such as investment or education.

Singh et al. (2010) investigate the determinants and the macro-economic role of remittances in Sub-Saharan Africa, with a dataset for 36 countries for 1990 through 2008, and incorporate data on the size and location of the Diaspora. The study finds that remittances are larger for countries with a larger Diaspora or when the Diaspora is located in wealthier countries, and that they behave counter-cyclically, consistent with a role as a shock absorber. Although the effect 
of remittances in growth regressions is negative, the authors posit that countries with wellfunctioning domestic institutions seem nevertheless to be better at unlocking the potential for remittances to contribute to faster economic growth.

As the foregoing review of the literature on Sub-Saharan Africa indicates, not only do the few available studies offer inconclusive results, just like other cross-country studies of developing countries, but they are equally subject to the restrictive assumptions of cross-sectional homogeneity across the sampled countries, an assumption that is not supported by the fact that while remittances constitute an insignificant proportion of the size of the economies of most of the countries in SSA (and Sub-Saharan Africa, relative to other regions of the world), they constitute an overwhelming proportion of the real GDP in some of the countries. Moreover, the World Bank $(2009 ; 2011)$ has emphasised the drawbacks of using data on international migrants' remittances in cross-country analysis, because this data often lacks in cross-country comparability, a caveat that potentially limits the reliability of outcomes of such cross-country pool analysis. The foregoing suggests that a richer analysis of the role of remittances in the region will be obtained from a country-specific analysis of the issues, especially in those countries with excessive inflows of remittances to their domestic economy.

There are a number of country-specific analyses of the effects of migrants' remittances on poverty and other household-level outcomes in Sub-Saharan Africa. These include Gustafsson and Makonnen (1993) for Lesotho; Adams (2006), Quartey and Blankson (2004); Adams, Cuecuecha, and Page (2008a, 2008b) for Ghana; Wouterse (2010) Lachaud (1999), for Burkina Faso; Odozia, Awoyemia, and Omonona (2010) for Nigeria; Nagarajan (2009) for South Africa; Birdsall and Chuhan (1986) for Mali; Lucas and Stark (1985) for Botswana; Mohapatra, Joseph, and Ratha (2009) for Ethiopia. An analysis of the effects of migrants' remittances on growth outcomes at the country level is to the best of our knowledge non-existent. This is argued to be a substantial gap in migration literature in the sub-region, especially considering the fact that its effects on growth performance reinforce its effects on poverty and other household-level outcomes. To fill this gap, this study investigates the short- and long-run impact of remittances on GDP growth, using country-level data on five selected Sub-Saharan African countries: Cape Verde, Lesotho, Nigeria, Senegal and Togo,.

\section{METHODOLOGY}

\subsection{Estimation issues and empirical model}

The review of existing remittances-growth literature in the preceding section indicates that the sign (and even the magnitude) of worker remittances in growth regressions remains inconclusive in the literature. It traverses, as observed by Barajas et al. (2009), from negative effects, to no discernible effects, to positive effects, and conditional effects. Chami et al. (2008) and Barajas et al. (2009) have identified the sources of the disparity in the coefficient of remittances in growth regressions to include the underlying data used to construct the time series for remittances, the differing time periods and sets of countries included. Others are the control variables included in the growth regressions - in particular, the presence of investment and human capital as a control variable and the wide variation in the choice of variables used as instruments for remittance flows in instrumental variables regressions (Chami et al., 2009) and most of the subsequent literature contained detailed discussions of these issues). 
These issues guide the selection and measurements of variables in the growth regressions that are subsequently estimated in the study, utilising particularly the "best practice" for estimating the remittances-growth relationship as identified in the review contained in Chami et al. (2009).

To achieve the objective of this study, the Barro (1996) type of extended neoclassical growth model was augmented with the remittances variable as one of the sources of growth. Within this framework, the growth equation can be expressed as:

$$
g_{t}=a_{0}+a_{1} r e m+\gamma A_{t}+\eta X_{t}+\varepsilon_{t}
$$

where $g$ is economic growth, and rem is the variable of interest remittances. $A$ is a set of state variables and $X$ is a set of choice or environmental variables that affect economic growth. In Barro (1996), the state variables include the initial level of GDP and measures of human capital in the forms of schooling and health. The environmental variables include the fertility rate, government consumption spending, an index of the maintenance of the rule of law, the change in the terms of trade, an index of democracy (political rights), and the inflation rate.

Drawing on the studies reviewed above, and particularly to the extent of the degree of freedom allowed by the relatively short dataset, the basic conditioning sets were limited to principal control variables employed in previous studies, to include initial per capita GDP, government consumption, all in log terms; and the inflation rate.

Following from the foregoing, $\varepsilon q(1)$ can be specified in its explicit form as follows:

$$
\operatorname{In}\left(g_{t}\right)=a_{0}+a_{1} \operatorname{In}\left(\text { rem }_{1}\right)+a_{2} \operatorname{In}\left(Y_{t-1}\right)+a_{3} \operatorname{In}\left(\text { gov }_{t}\right)+a_{4} i n f_{t}+\mu_{t}
$$

where $g$ is the growth rate of real GDP per capita, rem is remittances, $Y_{t-1}$ is the initial GDP per capita, govis government spending and inf is inflation. $\mu$ is the error term.

$Y_{t-1}$, measured as the lagged per capital real GDP, is the convergence term. According to Barro (1996), for given values of the other explanatory variables, the neoclassical model predicts a negative coefficient on initial GDP. The coefficient on the log of initial GDP has the interpretation of a conditional rate of convergence. If the other explanatory variables are held constant, then the economy tends to approach its long-run position at the rate indicated by the magnitude of the coefficient.

Remittances (rem) are measured by the ratio of remittances to GDP. Workers' remittances are as defined by the International Monetary Fund (IMF) in the Balance of Payments Statistics Yearbook. A common problem with studies on remittances, to which this study is subject, is appropriate measurements of the remittance variable. The IMF's Balance of Payment Statistics Yearbook (BOPSY) constructs total remittances as the sum of three items: "Workers' Remittances", "Compensation of Employees" and "Migrant Transfers". Giuliano and Ruiz-Arranz (2009) observe that the use of this definition entails the risk of including flows, such as earnings of locals working for foreign embassies and international organisations, which do not conform with the view that remittances typically refer to transfers of money by foreign workers to their home countries. Another problem is that other countries do not classify remittances separately from other current transfers in the balance of payments (BOP). In such cases, the standard definition understates the true flows. A related problem in remittance data is estimating informal flows such as remittances in kind, or money carried by friends or family members or through informal systems of money transfer. Unrecorded (informal) remittances are reputed to be close to $50 \%$ of total flows in economies with less-developed financial markets such as in our 
sample. As discussed previously, the sign of the coefficient associated with remittances remains indeterminate.

Government consumption ( $\mathrm{gov}$ ) is measured as the level of government consumption as a share of GDP. This variable approximates the burden of government. The greater the volume of nonproductive government spending and the associated taxation the lower the growth rate of GDP. Hence, a negative coefficient is expected for this variable.

Inflation (inf), measured as the annual percentage change in the consumer price index, is both an indicator of monetary policy (Fisher, 1993) and macro-economic stability. Higher inflation reduces real money balances and reflects weakness in macro-economic management. Both outcomes hamper private investment and saving decisions, thereby leading to an inefficient allocation of resources, which hampers growth. A negative coefficient estimate is thus expected for inflation.

The study is carried out for five Sub Saharan African countries for the period 1985-2009: Cape Verde, Lesotho, Nigeria, Senegal and Togo. The choice of countries was determined primarily by the preponderance of remittance flows to these countries as indicated in section 2, while availability of consistent data series on variables of interest was given consideration in determining the estimation period.

Annual data on the liquid liabilities of the financial system to GDP and the ratio of credit to the private sector to GDP was obtained from Beck et al. (2010), Financial Structure Dataset. Remittances, Growth and Openness variables were obtained from World Bank Development Indicators Database (Online), while inflation variable was obtained from International Financial statistics (IMF) Database (Online). All variables were modelled in their logarithmic transformations, except GDP growth rate and inflation volatility variables due to negative values in the series.

\subsection{Econometric procedure}

The study adopts the autoregressive distributed lag (ARDL) framework espoused in Pesaran and Shin (1999), Pesaran et al. (1996) and Pesaran and Pesaran (1997) to establish the cointegration relationship between economic growth, remittance inflows and other conditioning variables in selected countries.

The ARDL procedure has been popularised due to the following benefits over other multivariate co-integration techniques. One, as the name "autoregressive, distributed lags" suggests, refers to the lags of dependent and independent variables respectively. The approach thus allows both the dependent and independent variables to enter the model with lags, thereby allowing the past values of variables to determine their present values. This flexibility in terms of the structure of lags of the regressors is particularly plausible because reaction to a change in each variable may be different depending on various factors and in some cases they may respond to the changes in underlying factors with a lag. Thus there is usually no reason to assume that all regressors should have the same lags as suggested by the co-integration VAR models, where different lags for different variables are not permitted (Pesaran et al., 2001).

The second advantage of the procedure is its applicability irrespective of whether the regressors in the model are I(0), I(l) or mutually co-integrated. Thus, unlike other approaches, the bounds-testing procedure allows making inferences in the absence of any a priori information about the order of integration of the series under investigation. Strictly speaking, however, if 
the explanatory variables are integrated of order two, I(2), and/or the dependent variable is not $\mathrm{I}(1)$ process, then the bounds-testing approach cannot be used to determine the existence of co-integrating relations, as the F-test would be spurious in the presence of $I(2)$ because both the critical values of the F-statistics computed by Pesaran et al. (2001) and Narayan (2005) are based on the assumption that the variables are I(0) or I(l).

Third is the small sample property of the bounds-testing approach as argued in Narayan (2005). The ARDL is a more statistically significant approach for determining co-integrating relationships in small samples (Ghatak and Siddiki, 2001), while the Johansen co-integration techniques require large datasets. This makes this approach applicable to small samples, as is the case in this study.

Conventionally, the ARDL approach proceeds in three steps as espoused in Pesaran and Shin $(1995,1999)$. The first step involves establishing the existence of a long-run relationship between the variables. This is implemented by testing for the significance of lagged variables in an error-correction mechanism regression of Equation (2) augmented with the first lags of the levels of each variable.

The corresponding error correction version of the ARDL model for this study then becomes:

$$
\begin{aligned}
\Delta \operatorname{In} g_{t}= & a+\sum_{i=1}^{j} \beta_{1 i} \Delta \operatorname{Ing}_{t-1}+\sum_{i=0}^{j} \beta_{2 i} \Delta \operatorname{Inrem}_{t=i}+\sum_{i=0}^{j} \beta_{3 i} \Delta \operatorname{In} Y_{t-i}+\sum_{i=0}^{j} \Delta \operatorname{In} \beta_{4 i} g o v_{t-i} \\
& +\sum_{i=0}^{j} \Delta \beta_{5 i} \text { inf }_{t-i}+\delta_{1} \text { rem }_{t-1}+\delta_{2} Y_{t-1}+\delta_{3} \text { gov }_{t-1}+\delta_{4} i n f_{t-1}+\mu_{t}
\end{aligned}
$$

where $\Delta$ indicates first-difference operator, $j$ is the optimal lag length, $\delta_{i}$ are the long-run multipliers, and $I n$ is the natural logarithmic transformation of variables. The other notations remain as defined above. A Wald test for the joint significance of the coefficients of the lagged levels of the variables is conducted to test the existence of a long-run relationship, i.e., a test of the null hypothesis $H_{0}: \delta_{1}=\delta_{2}=\delta_{3}=\delta_{4}$ against the alternate $H_{1}: \delta_{1} \neq 0, \delta_{2} \neq 0, \delta_{3} \neq$ $0, \delta_{4} \neq 0$. The $F$-test is used for testing the existence of a long-run relationship. The $F$-test has a non-standard distribution which depends on whether variables included in the model are I $(0)$ or I(1). One set of critical values assumes that all variables included in the ARDL model are I(0), while the other is calculated on the assumption that the variables are I(l). If the Ftest statistics exceed their respective upper critical values, the conclusion will be that there is evidence of a long-run relationship between the variables regardless of the order of integration of the variables. If the test statistics are below the upper critical value, the null hypothesis of no cointegration cannot be rejected, and if it lies between the bounds, the result is inconclusive without knowing the order of integration of the underlying regressors.

The second step is to obtain the long-run dynamic parameters of the model by solving the restricted version of the equation for long-run solution once co-integration is established in the first step. The conditional $\operatorname{ARDL}\left(\tau, \eta_{1}, \eta_{2}, \eta_{3}, \eta_{4}\right)$ long-run model for $g_{t}$ is estimated as follows:

$$
\text { In } g_{t}=a+\sum_{j=1}^{r} \delta_{1} \text { In }_{t-1}+\sum_{i=0}^{\eta_{1}} \delta_{2} \operatorname{rem}_{t=i}+\sum_{i=0}^{\eta_{2}} \delta_{3} Y_{t-i}+\sum_{i=0}^{\eta_{4}} \delta_{4} \text { gov }_{t-1}+\sum_{i=0}^{\eta_{5}} \delta_{5} i n f_{t-1}+\mu_{t}
$$

where the orders or the optimal lag length of the $\operatorname{ARDL}\left(\tau, \eta_{1}, \eta_{2}, \eta_{3}, \eta_{4}, \eta_{5}\right)$ model in the variables were selected using Akaike information criteria (AIC). Finally, to obtain the short-run 
parameters, the error correction equation was estimated by using the differences of the variables and the lagged long-run solution, and determines the speed of adjustment of the growth variable to equilibrium as below:

$\Delta I n g_{t}=a+\sum_{i=1}^{r} \emptyset_{1} \Delta I n g_{t-i}+\sum_{j=0}^{\eta} \emptyset_{j} \Delta r e m_{t-j}+\sum_{l=0}^{\eta} \gamma_{1} \Delta Y_{t-l}+\sum_{s=0}^{\eta} \delta_{s} \Delta g o v_{t-s}+\sum_{p=0}^{\eta} \ell_{p} \Delta i n f_{t-p}+\psi e c m_{t-1}+\mu_{i}$

Where $\psi$ is the speed of adjustment, and $\phi, \varphi, \gamma, \vartheta$ and $\ell$ are the short-run dynamic coefficients of the model's convergence to equilibrium.

\section{EMPIRICAL RESULTS AND DISCUSSION}

The test for the stationarity status of all variables to determine their order of integration is necessary before proceeding with the ARDL bounds test, although the bounds-testing procedure is not predicated on prior information about the order of integration of the series under investigation. It is expedient, however, to ensure that the variables are not I(2) stationary so as to avoid spurious results. Inferences in the bounds-testing procedure through the computed Fstatistics for bounds testing are based on the assumption that the variables are level or firstdifferenced stationary. For this purpose the DF-GLS test for autoregressive unit roots advanced by Elliott, Rothenberg and Stock (ERS) (1996) was employed. This method proposes a simple modification of the ADF tests in which the data are detrended so that explanatory variables are "taken out" of the data prior to running the test regression. As documented in ERS (1996), this approach is preferred to the conventional ADF tests because it has the best overall performance in terms of sample size and power, and especially when an unknown mean or trend is present.

TABLE 2: Summary of Unit roots tests

\begin{tabular}{cccccc}
\hline Log Levels (Zt) & Cape Verde & Lesotho & Nigeria & Senegal & Togo \\
\hline$g_{t}$ & $\mathrm{I}(\mathrm{l})$ & $\mathrm{I}(\mathrm{l})$ & $\mathrm{I}(\mathrm{l})$ & $\mathrm{I}(\mathrm{l})$ & $\mathrm{I}(\mathrm{l})$ \\
$Y_{t}$ & $\mathrm{I}(\mathrm{l})$ & $\mathrm{I}(\mathrm{l})$ & $\mathrm{I}(\mathrm{l})$ & $\mathrm{I}(\mathrm{l})$ & $\mathrm{I}(\mathrm{l})$ \\
rem $t$ & $\mathrm{I}(\mathrm{l})$ & $\mathrm{I}(\mathrm{l})$ & $\mathrm{I}(\mathrm{l})$ & $\mathrm{I}(1)$ & $\mathrm{I}(\mathrm{l})$ \\
gov & $\mathrm{I}(\mathrm{l})$ & $\mathrm{I}(\mathrm{l})$ & $\mathrm{I}(\mathrm{l})$ & $\mathrm{I}(1)$ & $\mathrm{I}(\mathrm{l})$ \\
Inf & $\mathrm{I}(\mathrm{l})$ & $\mathrm{I}(0)$ & $\mathrm{I}(\mathrm{l})$ & $\mathrm{I}(0)$ & $\mathrm{I}(1)$ \\
\hline
\end{tabular}

Source: Authors' analysis

The DF-GLS statistics are compared to the $95 \%$ simulated critical value using 23 obs. and 1000 replications computed by stochastic simulations from Microfit for the test for each order of augmentation. The test regression included a constant and trend for the log-levels and only a constant for the first differences of the variables. (Details of unit roots tests results are available from the authors.)

The summarised DF-GLS unit test results for all variables and across selected countries are reported in TABLE 2. The DF-GLS unit root tests results for the variables reported in TABLE 1 indicate that all variables are I(1), with the exception of the inflation variables in Lesotho and Senegal, where there was no evidence to reject the null hypothesis of unit root at levels of the series. 
TABLE 3: ARDL Bounds test for cointegration

\begin{tabular}{cccccc}
\hline Model & Cape Verde & Lesotho & Nigeria & Senegal & Togo \\
\hline$F_{g}(g / Y$, rem, gov, inf $)$ & $3.924^{\star}$ & $4.11^{\star}$ & 6.14* & 2.68 & 2.17 \\
Critical Values $^{a}$ & & Lower Bound & & & Upper bound \\
$\mathrm{K}=5 ; \mathrm{n}=25$ & & & & \\
$10 \%$ & 2.578 & & & 3.858 \\
$5 \%$ & 3.125 & & & 4.608 \\
$1 \%$ & 4.537 & & & 6.370 \\
\hline
\end{tabular}

Source: Authors' analysis

Narayan (2005): Critical values for the bounds test: case III: unrestricted intercept and no trend

The asterisks indicated the level of significance: $\star \star 5 \%, \star 10 \%$. The critical values reported in Pesaran et al. (2001) are based on large sample sizes; thus, they cannot be used for small sample sizes. Narayan (2004 a, b) generates and reports new sets of critical values for small sample sizes ranging from 30 observations to 80 observations.

TABLE 3 reports the results of the ADRL bounds co-integration tests. It shows the calculated Fstatistics when the regressions are normalised on the $g$ (economic growth) variable. The search for co-integrating relations has been restricted to the growth variable as the dependent variable based on the fact that the study strictly used a growth regression model.

The computed F-statistics for Cape Verde, Lesotho and Nigeria are all higher than the upper critical bound at $10 \%$ critical value as indicated in TABLE 3 . This provided evidence to reject the null hypothesis of no co-integration at the $10 \%$ significance level for the growth models in Cape Verde, Lesotho and Nigeria. For Senegal, the computed F-statistics of 2.68 lie between the lower and upper critical bounds at $10 \%$ critical value; this, in the context of Pesaran and Shin (1995, 1999), offers inconclusive evidence. However, recourse to the order of integration of the regressors suggests an acceptance of the null hypothesis of no co-integration, since the regressors in this equation are mostly I(1). Similarly, the null hypothesis is not rejected for Togo, with computed F-statistics of 2.17, which is lower than the lower bounds at all critical values. It can therefore be concluded from the ARDL bounds test that there is a long-run relationship between economic growth, remittances and the forcing variables in Cape Verde, Lesotho and Nigeria, but the results prove otherwise in Senegal and Togo.

Having established that there is a long-run co-integration relationship for the models representing the data for Cape Verde, Lesotho and Nigeria, the long-run and short-run dynamic parameters for the models represented by these countries' data were obtained. The empirical results of the long-run model, obtained by normalising the economic growth variables for the three countries, are presented in TABLE 4, while the results of the error-correction model for the growth regressions are presented in TABLE 5 . 
TABLE 4: Estimated ARDL Long-Run Coefficients.

\begin{tabular}{|c|c|c|c|}
\hline Regressors & $\begin{array}{c}\text { Cape Verde } \\
\left(\operatorname{ARDL}(1,0,1,0,0)^{a}\right.\end{array}$ & $\begin{array}{c}\text { Lesotho } \\
\left(\operatorname{ARDL}(1,0,0,0,0)^{a}\right.\end{array}$ & $\begin{array}{c}\text { Nigeria } \\
\left(\operatorname{ARDL}(1,0,0,0,0)^{a}\right.\end{array}$ \\
\hline C & $\begin{array}{c}0.014 \\
(0.0446) \\
{[0.965]}\end{array}$ & $\begin{array}{l}.16382 \\
(1.508) \\
{[0.147]}\end{array}$ & $\begin{array}{l}2.444^{\star} \\
(4.425) \\
{[0.000]}\end{array}$ \\
\hline $\ln Y_{t}$ & $\begin{array}{c}0.0348 * \\
(2.23) \\
{[0.037]}\end{array}$ & $\begin{array}{c}0.116^{\star} \\
(2.07) \\
{[0.044]}\end{array}$ & $\begin{array}{l}0.0143 \\
(0.044) \\
{[0.965]}\end{array}$ \\
\hline Inrem $_{t}$ & $\begin{array}{l}0.605^{\star} \\
(1.877) \\
{[0.036]}\end{array}$ & $\begin{array}{c}-0.002 \\
(-1.544) \\
{[0.129]}\end{array}$ & $\begin{array}{l}0.441^{\star} \\
(3.444) \\
{[0.001]}\end{array}$ \\
\hline Ingov & $\begin{array}{c}0.165 \\
(0.074) \\
{[0.462]}\end{array}$ & $\begin{array}{l}-0.034^{\star} \\
(-2.23 .) \\
{[0.030]}\end{array}$ & $\begin{array}{c}0.221 \\
(0.116) \\
{[0.556]}\end{array}$ \\
\hline inf & $\begin{array}{c}0.062 \\
(1.37) \\
{[0.172]}\end{array}$ & $\begin{array}{c}-0.2982 \star \\
(-3.152) \\
{[0.003]}\end{array}$ & $\begin{array}{c}-0.091 \\
(-0.881) \\
{[0.3828]}\end{array}$ \\
\hline
\end{tabular}

Source: Authors' analysis

a. selected based on Akaike information criteria. $t$-statistics and $P$-values in (...) and [...] respectively.

The estimated coefficients of the long-run relationship show that, lagged GDP per capita, the convergence term is significantly positive for Cape Verde and Lesotho, but insignificant for Nigeria. The significantly positive coefficient associated with initial income negates the conditional convergence hypothesis. Once the determinants of their steady state are held constant, the convergence hypothesis postulates a negative coefficient of the convergence term that ensures poor economies tend to grow faster than rich economies. This outcome suggests that the poor African countries in the sample were growing at a slower pace than the rich economies during the sampled period.

Remittance, which is the variable of interest, produced mixed results, in line with the inconclusiveness of evidence of existing literature. The long-run ARDL estimates indicate positive and significant effects of migrants' remittances on growth performance in Cape Verde and Nigeria, but negative, and slightly significant at $13 \% \mathrm{t}$-value for Lesotho. These findings conform with, and are explained by, previous studies on growth effects of remittances in SubSaharan Africa. Such studiers include Fayissa and Nsiah (2008), who documented positive impacts on economic growth, Baldé (2009), who found that remittances do not have any direct impact on economic growth of Sub-Saharan African countries, and Singh et al. (2010), who found the effect of remittances in growth regressions to be negative in Sub-Saharan Africa.

The government consumption (gov) variable is correctly signed and statistically significant for Lesotho, but not important in explaining growth in Cape Verde and Nigeria. This finding however negates anecdotal experiences and realities in most African countries, where wasteful and corrupt government spending negatively affects economic development. Similarly, inflation matters for growth, and was correctly signed only in Lesotho and not in Cape Verde and Nigeria. 
TABLE 5: Error Correction Representation for the Selected ARDL Model

\begin{tabular}{|c|c|c|c|}
\hline Countries & Regressors & Coefficients & (t-stat) \\
\hline \multicolumn{4}{|c|}{ Cape Verde $[\operatorname{ARDL}(1,0,0,0,1)]^{\mathrm{b}}$} \\
\hline & $\Delta \ln y_{t}$ & $-4.78^{\star}$ & $(-6.12)$ \\
\hline & $\Delta$ rem & $0.241^{\star}$ & $(2.85)$ \\
\hline & $\Delta g o v$ & $-0.86 \star$ & $(-2.53)$ \\
\hline & $\Delta$ inf & 0.45 & $(0.98)$ \\
\hline & $\operatorname{ecm}(-1)$ & $-0.32^{\star}$ & $(-3.22)$ \\
\hline \multicolumn{4}{|l|}{ Lesotho $\left(\operatorname{ARDL}(0,0,0,0,1)^{b}\right.$} \\
\hline & $\Delta \ln y_{t}$ & $0.446 *$ & $(3.07)$ \\
\hline & $\Delta r e m$ & $-1.79 \star$ & $(-2.98)$ \\
\hline & $\Delta g o v$ & 1.45 & $(1.12)$ \\
\hline & $\Delta$ inf & 0.43 & $(0.92)$ \\
\hline & ecm $(-1)$ & $-1.81^{\star}$ & $(-3.16)$ \\
\hline \multicolumn{4}{|l|}{ Nigeria ARDL $(1,0,0,0,1)^{b}$} \\
\hline & $\Delta \ln y_{t}$ & $-1.79 *$ & $(-2.98)$ \\
\hline & $\Delta$ rem & $1.31 *$ & $(1.74)$ \\
\hline & $\Delta g o v$ & -0.06 & $(-0.85)$ \\
\hline & $\Delta$ inf & -0.13 & $(-0.14)$ \\
\hline & $\operatorname{ecm}(-1)$ & $-0.70 *$ & $(-4.40)$ \\
\hline
\end{tabular}

Source: Authors' analysis

Selected based on Akaike information criteria

TABLE 5 gives the results of the short-run dynamic coefficients associated with the long-run relationships obtained from the $\varepsilon C M$ equation. The error correction terms in all the models are highly significant and correctly signed, indicating adjustment to long-term equilibrium in the dynamic model. Bannerjee et al. (1998) posit this as evidence of a stable long-term relationship. The coefficients of error correction term are equal to $(-0.32),(-1.81)$ and $(-0.70)$ for Cape Verde, Lesotho and Nigeria models respectively. This implies that deviations from the long-term growth rate in GDP are adjusted relatively quickly.

Specification problems associated with serial correlation, normality or heteroscedasticity were checked with diagnostic tests, including the test for serial correlation (LM test), heteroscedasticity (ARCH test), normality $(\mathrm{JB}(\mathrm{N})$ ) and functional form. All tests confirmed the appropriateness of the $\varepsilon C M$ model across the countries. Further, the stability of the long-run coefficients, along with the short-run dynamics of the estimated ARDL model, was confirmed with the CUSUM and CUSUMP tests. TABLE 6 presents the plots of the CUSUM and CUSUMP based 
on the on AIC criterion. As can be seen in TABLE 6, all plots remain within critical bounds at $5 \%$ significance, accepting the null hypothesis that all coefficients and the ECM are stable.

\section{SUMMARY AND CONCLUSION}

The study examines the supposition that 'size matters' in the empirical controversy of the remittances-growth nexus by way of an empirical analysis of the issue in selected countries in Sub-Saharan Africa, where remittance inflows constitute a significant proportion of real GDP. The study used data at the country level, and particularly for five countries: Cape Verde, Lesotho, Nigeria, Senegal and Togo. The long-run ARDL estimates indicate positive and significant effects of migrants remittances on growth performance in Cape Verde and Nigeria, but negative and slightly significant effects for Lesotho, with no evidence of long-run level relationships between remittances and economic growth in Senegal and Togo. The conjecture that size may matter in the remittance-growth nexus finds no support, as findings provide no significant departure from the existing inconclusiveness of the empirical literature on the relationship, notwithstanding that the modelling and estimation procedures take cognisance of some of the sources of disparities in the findings of previous literature.

These results therefore underscore the importance of the argument that whether remittances increase an economy's growth depends on whether conditions prevalent in the recipient economy are amenable to the operation of the channels through which remittances may retard or promote growth (or be entirely insignificant) discussed previously. Particularly relevant in explaining the mixed results across the selected countries is the near consensus that financial intermediation tends to increase the responsiveness of growth to remittances. (See Aggrawal et al., 2010; Fajnzylber \& Lopez, 2008; and Gupta et al., 2009, among others.)

While remittance inflows are significant for all the selected countries, there are wide and diverging differences with the structure and level of development of their financial sectors. For instance, anecdotal evidence suggests that Cape Verde and Nigeria, which exhibit a positive response of growth performances to remittance inflows, have relatively more developed financial systems than Lesotho, Senegal and Togo, which present contrasting results.

While evidence on its growth-promoting role remains mixed and inconclusive, there is no denying the fact that remittances remain an important link between migration and development, especially in poor labour-exporting countries in Sub-Saharan Africa. This study advocates country-level policies that make financial services more generally available, which should lead to better use of remittances, thus boosting growth in these countries. In addition, improvement in the efficiency of remittance inflows and promoting the use of remittances for developmental purposes are important policy directions in these countries.

\section{LIST OF REFERENCES}

Acosta, P.A., Emmanuel, K.K. \& Mandelman, F.S. (2007). Remittances and the Dutch Disease. Federal Reserve Bank of Atlanta. (Working paper no. 2007-8).

Adams, R.H. (2006). Remittances and Poverty in Ghana. World Bank Policy.(Research paper, p. 3838). 
Adams, R.H., Cuecuecha, A. \& Page, J. (2008a). The Impact of Remittances on Poverty and Inequality in Ghana. World Bank, Washington, DC. (Policy Research Working Paper 4732).

Adams, R.H., Cuecuecha, A. \& Page, J. (2008b). Remittances, Consumption and Investment in Ghana. World Bank, Washington, DC. (Policy Research Working Paper 4515).

Aggrawal, R., Demirgüç-Kunt, A., Martinez Peria, M.S. (2011). Do Remittances promote Financial Development? Journal of Development Economics, 96(2), November 2011.

Ahlburg, D. (1991). Remittances and Their Impact, A study of Tonga and Western Samoa. The Australian National University, Canberra. (Pacific Policy Paper No.7).

Amuedo, D. \& Pozo, S. (2004). Workers Remittances and the Real Exchange Rate: A Paradox of Gifts. World Development, 32(8), pp. 1407-1417.

Baldé, Y. (2009). Migrants' Remittances and Economic Growth in Sub-Saharan Africa. Laboratory of Economic Analysis and Prospective (LAPE). University of Limoges, France. (UNESCAP Working Paper 7).

Bannerjee, A., Dolado, J. \& Mestre, R. (1998). Error-correction mechanism tests for cointegration in single equation framework. Time Series Analysis, 19, pp. 267-283.

Barajas, A., Chami, R., Fullenkamp, C., Gapen, M. \& Montiel, R. (2009). Do Workers' Remittances Promote Economic Growth?, IMF Washington, D.C., International Monetary Fund. (IMF Working Paper, WP/09/153).

Barro, R. (1996). Determinants of Economic Growth: A Cross-Country Empirical Study. National Bureau of Economic Research. (NBER Working Paper 5698).

Beck, T. (2009). The Econometrics of Finance and Growth. In Terrence Mills and Kerry Patterson (eds.), Palgrave Handbook of Econometrics. Vol.2. Hampshire, U.K.: Palgrave Macmillan.

Birdsall, N. \& Chuhan, P. (1986). Client Choice of Health Care Treatment in Rural Mali. World Bank, Health, Nutrition and Population Department, Washington, DC.

Bugamelli, M. \& Paterno, F. (2009). Do Workers' Remittances Reduce the Probability of Current Account Reversals? World Development37(12), pp. 1821-1838.

Catrinescu, N., Leon-Ledesma, N., Piracha, M. \& Quillin, B. (2008). Remittances, institutions and economic growth. World Development, 37(1), pp. 81-92.

Chami, R., Barajas, A., Cosimano, T. Fullenkamp, C., Gapen, M. \& Montiel, P. (2009). Macro-economic Consequences of Remittances. Washington: International Monetary Fund. (IMF Occasional Paper No. 259).

Chami, R., Fullenkamp, C. \& Jahjah, S. (2003). Are Immigrant Remittance Flows a Source of Capital for Development? International Monetary Fund, Washington DC. (IMF Working Paper 01/189).

Chami, R., Cosimano, T.F. \& Gapen, M.T. (2006). Beware of Emigrants Bearing Gifts: Optimal Fiscal and Monetary Policy in the Presence of Remittances. Washington: International Monetary Fund. (IMF Working Paper 06/61).

Cruz, Z.M. (2011). On the Path to Economic Growth, Do Remittances Help? Evidence from Panel VARs. The Developing Economies, 49(2), pp. 171-202.

Elliot, G., Rothenberg, T.J. \& Stock, J.H. (1996). Efficient tests for an autoregressive unit root. Econometrica, 64, pp. 813-836.

Faini, R. (2006). Migration and Remittances: The Impact on the Countries of Origin, University of Rome.[Online] Available: http://www.eudnet.net/download/Faini.pdf. (Accessed 10 February 2011). 
Fajnzylber, P. \& López, H., (2008). Remittances and Development: Lessons from LatinAmerica. World Bank, Washington, DC.

Fayissa, B. \& Nsiah, C. (2008). The impact of remittances on economic growth and development in Africa. Department of Economics and Finance (working paper series).

Fischer, S. (1993). The Role of Macro-economic Factors in Growth. Journal of Monetary Economics,. 32(3), pp. 485-512.

Freund, C.L. \& Spatafora, N. (2005). Remittances: Transaction Costs, Determinants, and Informal Flows. World Bank. (Policy Research Working Paper 3704).

Ghatak S. \& Siddiki, J. (2001). The use of ARDL approach in estimating virtual exchange rates in India. Journal Applied Statistics, 28, pp. 573-583.

Giuliano, P. \& Ruiz-Arranz, M. (2005). Remittances, Financial Development, and Growth, 4, International Monetary Fund. Washington DC. (IMF Working Paper 05/23).

Giuliano, P. \& Ruiz-Arranz, M. (2009). Remittances, Financial Development, and Growth. Journal of Development Economics, 90, pp. 144-152.

Gupta, S., Pattillo, C. \& Wagh, S. (2009). Effect of Remittances on Poverty and Financial Development in Sub-Saharan Africa. World Development, 37 (1), pp. 104-115.

Gustafsson, B. \& Makonnen, N. (1993). Poverty and Remittances in Lesotho. Journal of African Economies, 2(2), pp. 49-73.

Hnatkovska, V. \& Loayza, N., (2003). Volatility and Growth. World Bank. (Working Paper No. 3184).

IMF (2005) World Economic Outlook, International Monetary Fund, Washington DC.

Itzigsohn, J. (1995). Migrant Remittances, Labor Markets, and Household Strategies: A Comparative Analysis of Low-Income Household Strategies in the Caribbean Basin. Social Forces, 74, pp. 633-655.

Kapur, D. \& McHale, J. (2005). Give Us Your Best and Brightest: The Global Hunt for Talent and Its Impact on the Developing World. Washington, DC: Center for Global Development.

Ketkar, S. \& Ratha, D. (2009a). Innovative Financing for Development. World Bank, Washington DC.

Ratha, D., Mohapatra, S. \& Plaza, S. (2009). Beyond Aid: New Sources and Innovative Mechanisms for Financing Development in Sub-Saharan Africa. In Innovative Financing for Development, ed. Suhas Ketkar and Dilip Ratha, pp. 143-183. Washington, DC: World Bank.

Kozel, V. \& Alderman, H. (1990). Factors Determining Work Participation and Labour Supply Decisions in Pakistan's Urban Areas. Pakistan Development Review, 29, pp. 1-18.

Kroft, K. \& Lloyd-Ellis, H. (2002). Further Cross-Country Evidence on the Link Between Growth, Volatility and Business Cycles. (Queens University Working Paper).

Lachaud, J-P. (1999). Envoi de fonds, inégalité et pauvreté au Burkina Faso. University of Bordeaux IV: Bordeaux. (Working paper, Center for Development Economics)

Levine, R., (2005). Finance and growth: theory and evidence. In: Aghion, P., Durlauf, S. (eds.), Handbook of Economic Growth. Elsevier, Amsterdam.

Lucas, R. \& Stark, 0. (1985). Motivations to Remit: Evidence from Botswana. Journal of Political Economy, 93, pp. 901-918.

Mishra, P. (2005). Macro-economic Impact of Remittances in the Caribbean. Unpublished (paper). International Monetary Fund, Washington, DC. 
Mohapatra, Sanket, George Joseph, and Dilip Ratha. (2009). Remittances and Natural Disasters: $E x-$ Post Response and Contribution to $\varepsilon_{X}$-Ante Preparedness. World Bank, Washington, DC. . (Policy Research Working Paper 4972).

Nagarajan, S. (2009). Migration, Remittances, and Household Health: Evidence from South Africa. Ph.D. dissertation, Department of Economics: George Washington University, Washington, DC.

Narayan, P.K. (2004a). The saving and investment nexus for China: Evidence from cointegration test. Applied economics, 37, pp. 1979-1990.

Narayan, P.K. (2004b). The structure of tourist expenditure in Fiji: Evidence from unit root structural break tests. Applied Economics, 37, pp. 1157-1161.

Narayan, P.K., \& Narayan, S. (2005). Estimating income and price elasticities of imports for Fiji in a cointegration framework. Economic Modelling, 22, pp. 423-438.

Narayan, P.K. (2005). Reformulating critical values for the bounds F-statistics approach to cointegration: an application to the tourism demand model for Fiji. Department of Economics, Monash University, Melbourne, Australia. (Discussion Papers N0.02/04).

Odozia, J.C., Awoyemia, T.T. \& Omonona, B.T. (2010). Household Poverty and Inequality: The Implication of Migrants' Remittances in Nigeria. Journal of Economic Policy Reform, 13 (2), pp. 191199.

Orozco, M. \& Fedewa, R. (2005). Leveraging Efforts on Remittances and Financial Intermediation. Report Commissioned by the Inter-American Development Bank.

Pesaran, M.H. \& Pesaran, B. (1997). Working with Microfit 4.0: Interactive econometric analysis. Oxford: Oxford University Press.

Pesaran, M.H. \& Shin, Y. (1999). An autoregressive distributed lag modelling approach to cointegration analysis. In S. Strom (ed), Econometrics and Economic Theory in the 20 Century: The Ragnar Frisch Centennial Symposium, Cambridge, Cambridge University Press.

Pesaran, M.H., Shin, Y. \& Smith, R.J. (1996). Testing for the Existence of a Long Run Relationship. University of Cambridge, Cambridge.

Pesaran, M.H., Shin, Y.C. \& Smith, R. (2001). Bound testing approaches to the analysis of level relationships. Journal of Applied Econometrics, 16, pp. 289-326.

Pesaran, M.H. \& Shin, Y. (1995). An Autoregressive Distributed Lag Modelling Approach to Cointegration Analysis. Department of Applied Economics, University of Cambridge. (DAE Working Paper no 9514).

Pradhan, G., Upadhyay, M. \& Upadhyaya, K. (2008). Remittances and economic growth in developing countries. The European Journal of Development Research, 20(3), pp. 497-506.

Quartey, P. \& Blankson, T. (2004). Do migrant remittances minimize the effect of macro-volatility on the poor in Ghana? [Online] Available: http://www.gdnet.org/

pdf2/gdn_library/global_research_projects/macro_low income/Quartey.pdf. (Accessed 10 February 2011)

Ramey, G. \& Ramey, V.A. (1995). Cross-country evidence on the link between volatility and growth. American Economic Review, 85 (5), pp. 1138-1151.

Bhaskara, R.B. \& Hassan, G.M. (2011). A panel data analysis of the growth effects of remittances. Economic Modelling, 28, pp. 701-709. 
Ratha, D. (2005). Remittances: A Lifeline for Development. Finance Dev., 42(4), pp. 42-43.

Shimeles, A. (2010). Diaspora Bonds and Securitization of Remittances for Africa's Development. Africa Economic Brief, Volume 1,Issue 7.December 2010. AFDB.

Singh R.J., Haackerb, M., Kyung-Woo, L. \& Le Goff, M. (2010). Determinants and Macroeconomic Impact of Remittances in Sub-Saharan Africa. Journal of African Economies, 20(2), pp. 312-340.

Solimano, A. (2003). Remittances by Emigrants: Issues and Evidence. World Institute for Development Economics Research, United Nations University, Helsinki. (WIDER Discussion Paper No. 2003/89)

Stark, 0. \& Levhari, D. (1982). On Migration and Risk in LDCs', Economic Development and Cultural Change, 31(1), pp. 191-196.

World Bank (2006) Global Economic Prospects 2006, The International Bank for Reconstruction and Development / The World Bank

World Bank. (2009). Migration and Remittances Factbook 2008 (Washington: World Bank).

World Bank. (2011). Migration and Remittances Factbook 2011 (Washington: World Bank).

World Bank. (2010). Outlook for Remittance Flows 2010-2011. Migration and Development Brief, World Bank, Washington, DC.

Wouterse, F. (2010). Remittances, Poverty, Inequality and Welfare: Evidence from the Central Plateau of Burkina Faso. Journal of Development Studies, 46(4), pp. 771-789.

Yang, D. (2005). International Migration, Human Capital, and Entrepreneurship: Evidence from Philippine Migrants Exchange Rate Shocks. Ford School of Public Policy, University of Michigan, Ann Arbor. (Working Paper No. 02-011) 